\title{
Growth and Physiology of Boston Fern (Nephrolepis exaltata) as Influenced by Different Coloured Shade Nets
}

\author{
N. Naveena ${ }^{1 *}$, S. P. Thamaraiselvi ${ }^{1}$, K. R. Rajadurai ${ }^{2}$ and R. Sivakumar ${ }^{3}$ \\ ${ }^{1}$ Department of Floriculture and Landscape Architecture, Tamil Nadu Agricultural \\ University, Coimbatore, India \\ ${ }^{2}$ Regional Research Station, Aruppukottai, India \\ ${ }^{3}$ Regional Research Station, Paiyur, India \\ *Corresponding author
}

\section{A B S T R A C T}

\section{Keywords}

Cut foliage, Boston fern, Nephrolepis exaltata, Coloured shade nets, Growth, Physiology

\section{Article Info}

Accepted: 04 September 2020 Available Online: 10 October 2020
Protected cultivation of Nephrolepis exaltata L. plants paved way to increase its cut foliage value in the market by providing suitable micro climate conditions for growth and development. The present study was focused on evaluating the foliage fern viz., Boston fern under different coloured shade nets viz., red, white, green, black and control as natural shade. Environmental parameters viz., light intensity, temperature and relative humidity recorded during the entire study period indicated that highest light intensity was recorded under red coloured shade net as well as in control. No significance change was found in temperature and relative humidity under different coloured shade nets. Most of the growth parameters were found to be superior in the plants grown under red net conditions where it received maximum light intensity throughout the growth period.

\section{Introduction}

Cut foliage plants are important component in floricultural industry. They are widely used for decoration purpose which provides freshness, colour and variety to the flower arrangements and bouquets. Many of the cut foliage plants have been claimed as important fillers in stage decorations. The commercial production of cut foliage plants has begun in India in recent years and these plants have huge demand in the market. Nephrolepis exaltata (Boston fern) belongs to the family
Nephrolepidaceae and is a very popular house plant, often grown in hanging baskets or similar conditions. This fern thrives best in humid conditions and in outdoors and it prefers partial shade or full shade, while indoors it grows best in bright filtered light. Generally foliage plants perform well under partial shade and produces foliage round the year. Coloured shade nets approach has already been successfully experimented in certain ornamentals, vegetable and even fruit crops. Providing shade nets regardless of colour reduce radiation that reaches the crops 
underneath and is directly proportional to the shade factor and modify microenvironment. Hence the present investigation was carried out with the objective of growing good quality cut foliage Nephrolepis fern plants under different coloured shade nets and to find the suitable coloured net for best foliage growth and quality.

\section{Materials and Methods}

The experiment was conducted at the Department of Floriculture and Landscape Architecture, Coimbatore, Tamil Nadu located at $11^{0} 02$ ' $\mathrm{N}$ latitude and $76^{\circ} 57^{\prime} \mathrm{E}$ longitude at an altitude of $426.76 \mathrm{~m}$ above MSL. The plants were grown and evaluated under different coloured shade nets $(50 \%$ shade level) viz., red, white, green, black and in natural tree shade as control. Uniform sized plants were selected and planted in pots of 20 $\mathrm{cm}$ diameter ( $1 / 4$ size pots). The growing media used for planting comprised of sand, garden soil and red soil in the ratio 1:1:1. The experiment was laid out in FCRD (Factorial Completely Randomized Design) with two factors and three replications. Coloured shade nets and duration of months after planting were the two factors. Environmental parameters were recorded regularly @ 9.00 AM, 12.00 Noon and 3.00 PM in a day. Temperature, relative humidity and light intensity were recorded using thermometer, hygrometer and lux meter respectively (Average value of the individual parameters was calculated throughout the growth period and the compiled date is furnished in Table 1). Morphological and quality parameters (Vase life and leaf senescence) parameters were recorded @ $6^{\text {th }}$ month after planting during harvest whereas physiological parameters taken at 2 months interval and average been calculated. Vaselife of the cut fern was estimated in distilled water under ambient conditions.

\section{Results and Discussion}

The different shade net colours had a positive influence on morphological parameters of Nephrolepis exaltata L. Different coloured shadenets relieve light and heat stress caused during summer months. Plants grown under red shade net exhibited highest plant height, plant spread as well as number of pinnae/ plant recorded six months after planting (Table 2). Though during the initial growth phases, no significance was noticed during later stages of growth significant differences were observed in morphological as well as foliage quality. Similar increase in plant height of Pittosporum plants grown under red net has been reported by Oren-Shamir (2001).

Increase in plant height under red may be due to the reduced R:FR ratio or the deficiency of blue light (Kasperbauer, 1994). Blue light (blue net) causes dwarfing (Shahak, 2014); hence opposite of dwarfing is expressed in plant morphology. Considering pinna or leaf characters, highest pinna length, pinna breadth and pinna area was noticed in plants grown under red shade net (Table 2). Similar findings were reported by Rekha Meena et al., (2012) who conducted micro climatic studies in Spinacia olearecae and concluded that increased leaf area was obtained under red shade net conditions. Sufficient utilization of intercepted radiation might have occurred in red shade nets which in turn favoured highest leaf area.

One of the important parameter deciding the aesthetic appearance of the cut foliage is its internodal length and in the present study it was observed that plants grown under red shade net recorded highest internodal length (Table 2). This might be because of pronounced stimulation of the vegetative growth such as increased plant height and spread in case of red shade net conditions. 
Table.1 Effect of environmental parameters under different coloured shade nets during entire growth period

\begin{tabular}{|l|c|c|c|}
\hline Shadenet colours & Temperature $\left.\mathbf{(}^{\mathbf{0}} \mathbf{C}\right)$ & Relative humidity (\%) & Light intensity (lux) \\
\hline Red & 27.58 & 64.78 & 5616 \\
\hline White & 28.97 & 66.74 & 5422 \\
\hline Green & 27.88 & 66.33 & 4948 \\
\hline Black & 26.33 & 68.00 & 5158 \\
\hline Control & 27.48 & 65.83 & 5705 \\
\hline Mean & $\mathbf{2 7 . 6 5}$ & $\mathbf{6 6 . 3 4}$ & $\mathbf{5 3 7 0}$ \\
\hline
\end{tabular}

Table.2 Effect of coloured shade nets on morphological parameters of Nephrolepis exaltata @ 6 months after planting

\begin{tabular}{|c|c|c|c|c|c|c|c|c|c|}
\hline \multirow[t]{2}{*}{$\begin{array}{l}\text { Shade net } \\
\text { colour }\end{array}$} & \multirow{2}{*}{$\begin{array}{l}\text { Plant } \\
\text { height } \\
(\mathrm{cm})\end{array}$} & \multicolumn{2}{|c|}{$\begin{array}{c}\text { Plant spread } \\
(\mathbf{c m})\end{array}$} & \multirow{2}{*}{$\begin{array}{c}\text { Number } \\
\text { of } \\
\text { leaves/ } \\
\text { plant }\end{array}$} & \multirow{2}{*}{$\begin{array}{c}\text { Leaf } \\
\text { length } \\
(\mathrm{cm})\end{array}$} & \multirow{2}{*}{$\begin{array}{c}\text { Leaf } \\
\text { breadth } \\
(\mathrm{cm})\end{array}$} & \multirow{2}{*}{$\begin{array}{l}\text { Leaf } \\
\text { area } \\
\left(\mathrm{cm}^{2}\right)\end{array}$} & \multirow[t]{2}{*}{$\begin{array}{l}\text { Internodal } \\
\text { length }(\mathrm{cm})\end{array}$} & \multirow{2}{*}{$\begin{array}{c}\text { Petiole } \\
\text { girth } \\
\text { (cm) }\end{array}$} \\
\hline & & E-W & N-S & & & & & & \\
\hline Red & 51.26 & 43.27 & 47.71 & 204.67 & 3.20 & 0.50 & 4.78 & 3.80 & 0.55 \\
\hline White & 32.04 & 27.28 & 31.83 & 180.78 & 2.80 & 0.40 & 3.43 & 2.40 & 0.42 \\
\hline Green & 44.78 & 39.33 & 43.65 & 178.22 & 2.20 & 0.42 & 3.17 & 2.07 & 0.40 \\
\hline Black & 41.32 & 27.07 & 29.64 & 149.40 & 2.30 & 0.48 & 4.23 & 2.50 & 0.45 \\
\hline Control & 40.53 & 28.52 & 30.09 & 158.27 & 2.20 & 0.41 & 3.53 & 2.20 & 0.41 \\
\hline Mean & 42.00 & 32.89 & 36.58 & 174.27 & 2.52 & 0.44 & 3.83 & 2.62 & 0.45 \\
\hline S. Ed. & 4.31 & 3.40 & 3.80 & 13.45 & 0.23 & 0.04 & 0.34 & 0.23 & 0.04 \\
\hline CD (0.05) & 8.81 & 6.95 & 7.77 & 27.47 & 0.48 & NS & 0.69 & 0.51 & NS \\
\hline
\end{tabular}

*Pinna is represented as leaf

Table.3 Effect of coloured shadenets on physiological and quality parameters

\begin{tabular}{|c|c|c|c|c|c|}
\hline $\begin{array}{l}\text { Shadenet } \\
\text { colours }\end{array}$ & $\begin{array}{c}\text { Chlorophyll } \\
\text { content }\left(\mathrm{mg} \mathrm{g}^{-1}\right)\end{array}$ & $\begin{array}{c}\text { Photosynthetic } \\
\text { rate } \\
\left(\mu \mathrm{mol} \mathrm{m} \mathbf{~ s}^{-1}\right)\end{array}$ & $\begin{array}{c}\text { Epicuticular } \\
\text { wax } \\
\left(\mu \mathrm{g} \mathrm{cm}^{-2}\right)\end{array}$ & $\begin{array}{l}\text { Days taken for } \\
\text { leaf senescence } \\
\text { (days) }\end{array}$ & $\begin{array}{c}\text { Vase life in } \\
\text { distilled } \\
\text { water (days) }\end{array}$ \\
\hline Red & 1.23 & 2.29 & 2.04 & 25.34 & 4.50 \\
\hline White & 1.22 & 1.32 & 1.46 & 25.26 & 4.50 \\
\hline Green & 1.33 & 2.80 & 3.01 & 29.52 & 6.50 \\
\hline Black & 1.80 & 2.26 & 1.97 & 24.32 & 5.00 \\
\hline Control & 1.14 & 3.71 & 1.47 & 22.70 & 4.75 \\
\hline Mean & 1.33 & 2.48 & 1.97 & 25.43 & 5.05 \\
\hline S.Ed & 0.14 & 0.29 & 0.25 & 1.37 & 0.59 \\
\hline C.D (0.05) & 0.29 & 0.60 & 0.53 & 3.06 & 1.33 \\
\hline
\end{tabular}

Highest petiole girth was also recorded in plants grown under red shade net which is a desirable trait in cut foliage industry (Table
2). In support of this result, Mythrong and Sudhadevi (2016) reported that red shade net enhanced the petiole length and girth in 
Nephrolepis exaltata and Asparagus densiflorus. The shading of crops results in number of changes on both microclimate and crop activity. Shade netting not only decreases light quantity but also alters light quality to a varying extent which might also influence other environmental conditions.

It was found that red nets significantly increased the total yield as compared to black shade nets (Zoran et al., 2011). Light related stresses can be rectified specifically by using coloured shade nets. Red light spectrum reduces the blue, green, and yellow light spectrums and increases the R and FR light spectrums and hence causes stem elongation in plants (Oren-Shamir, 2001). The total chlorophyll was higher in leaves of plants grown under black net (Table 3) and this corroborates the findings of Stamp and Chandler (2008) who found greater chlorophyll content in Pittosporum tobira 'Variegata' under black and blue coloured nets. This fact is associated with the low levels of PAR and light intensity recorded under black net. Although the plants were not directly exposed to sun, they produced additional chlorophyll to capture the diffuse radiation in order to produce carbohydrates required for their growth and development (Ilic et al., 2015).

Among the different shadenet conditions, the highest photosynthetic rate was observed in control (tree shade) and this might be due to high $\mathrm{CO}_{2}$ prevailing in outer environment when compared to shade net conditions. Higher photosynthetic rate recorded in green net after control (Table 3) was attributed to the fact that, green colour might have scattered more light resulting in availability of more diffused radiation. This diffused radiation in turn causes higher absorption of PAR resulting in more light use efficiency and photosynthetic rate, whereas black colour acts as opaque material causing less reflection of all light spectra thereby reducing the light use efficiency, photosynthetic rate and ultimately reduction in yield. Similar results were recorded by Shahak (2008) and Zoran et al., (2011).

Longer vase life and longevity was found in the leaves harvested from green shadenet grown plants which possessed highest epicuticular wax content as well (Table 3). The deposition of epicuticular wax is continuous until complete morphological development of the leaf. Protected conditions always show increased epicuticular wax content than open/outside conditions.

The deposition rate of wax in leaf cuticle depends directly on temperature and light, being inversely proportional to water content in the plant (Skoss, 1955). Contrary to this earlier report, in the present study highest epicuticular wax was recorded under green net conditions which recorded reduced light intensity and temperature. Differential response occurs with regard to plant species and the prevailing environmental parameters. This increased wax content in green shade net grown plants may be due to suitable microclimate provided in favour of wax biosynthesis. Excess wax content on leaf surface might have provided better protection of the leaves from high light intensity/temperature and thereby improved the freshness of the cut foliage.

Not much variation between the climatic parameters was noticed under different coloured shadenets. Temperature ranged between 27 and $29^{\circ} \mathrm{C}$ in all the treatments on an average (Table 1). Temperature was highest under white shade net $\left(28.97^{\circ} \mathrm{C}\right)$ while it was least of $26.33^{0} \mathrm{C}$ under black shade net. Variation in temperature under different coloured shadenets was in agreement with earlier studies that reported reduced temperature under black shade nets which in 
turn affect plant processes (Smith et al., 1984). Relative humidity ranged between 64 to $68 \%$ in all the treatments. Relative humidity is often higher under netting than outside as a result of water vapour being transpired by the crop and reduced mixing with drier air outside the netted area (Elad et al., 2007), even when temperatures under the netting are higher than outside (Stamps, 1994) (Table 1). Among the different growing conditions, light intensity was highest (5705 lux) under control followed by red shade net. Average light intensity ranged between 6000 and 7000 lux experienced throughout the growing period (Table 1). Natural shade in outside environment ensured the maximum sunlight utilization or light fall in control. However, usage of coloured shade cloth is designed such that to modify light in either the ultra-violet, visible or far-red spectral regions; the cloth also enhances the relative content of scattered vs. direct light and absorbs infra-red radiation (Shahak, 2014), hence the plants can be grown without experiencing radiation related stresses.

In conclusion the bascially cut foliages are the source of decoration on its own or as a combination with other flowers in bouquets. Countries like Florida, Holland ventured into foliage cultivation to make the floral arrangement fulfilled. Moreover quality foliage production is met out by protected cultivation and shadenets potentially termed as low cost protected cultivation technology can be adopted easier to achieve this. In our study, growing of Nephrolepis fern plants under red shade net improved the growth parameters of Boston fern whereas greenshade nets positively influenced the quality of the foliage. Hence growth of Nephrolepis fern during initial phase under red shade net (upto four months) and shifting to green shade net (after six months of planting) can be followed for better morphological growth and better foliage quality during harvesting.

\section{References}

Elad, Y., Messika, Y., Brand, M., David, D.R. and Sztejnberg, A. 2007. Effect of colored shade nets on pepper powdery mildew (Leveillula taurica). Phytoparasitica, 35: 285-299.

Ilic,S.Z., Milenkovic, L. Sunic, L., Cvetkovic, D. and Fallik, E. 2015. Effect of coloured shade-nets on plant leaf parameters and tomato fruit quality. J. Sci. Food and Ag., 95: 2660-2667

Kasperbauer, M. J. 1994. Light and plant development. In: Wilkinson R.E. (Ed) plant -Environment Interactions. Marcel Dekker Inc. NY, pp: 83-123.

Oren-Shamir, M, Gussakovsky, E.E., Spiegel,E., Nissim-Levi,A., Ratner,K., Ovadia,R., Giller, Y.E. and Shahak,Y. 2001. Coloured shade nets can improve the yield and quality of green decorative branches of Pittosporum variegatum. J. Hort. Sci. Biotech, 76: 353-361.

Myrthong, A.L. and Sudhadevi, P.K. 2015. Performance evaluation of Nephrolepis exaltata and Asparagus densiflorus under different coloured shade nets. Inter. J. Ap. Pure Sci. Ag. 2(7): 113 117.

Rekha Meena, Ananta Vashisth, Singh, R., Balraj Singh and Manjaih, K. M. 2012. Micro Environment Study under Different Colour Shade Nets and its Effects on Biophysical Parameters in Spinach (Spinacia Oleracea) by Division of Agricultural Physics, IARI, New Delhi, NRCSS, Ajmer, Soil Science and Agricultural Chemistry, IARI, New Delhi

Shahak, Y. 2008. Photo-selective netting for improved performance of horticultural crops. A review of ornamental and vegetable studies carried out in Israel. Acta Hort., 770:161-168.

Shahak, Y. 2014. Photoselective netting: an overview of the concept, $\mathrm{R} \& \mathrm{D}$ and 
practical implementation in agriculture. Acta hort., 10(15): 155-162

Skoss, J.D .1955. Structure and composition of plant cuticule in relation to environmental factors and permeability. Botanical Gazette, 11: 55-72.

Smith, I.E., Savage, M.J. and Mills, P. 1984. Shading effects on greenhouse tomatoes and cucumbers. Acta Hort., 148: 491500

Stamps, R.H. 1994. Evapotranspiration and nitrogen leaching during leatherleaf fern production in shade houses (SJRWMD Spec. Publ. SJ94-SP10. St. Johns River Water Management District, Palatka, FL).
Stamps, R.H. and Chandler, A.L. 2008. Differential effects of coloured shadenets on three cut foliage crops. In: Proceedings XXVII IHC- International Symposium on Cultivation and Utilization of Asian, Sub-Trop., Underutilized Hort. Crops, 770:169-76.

Zoran I, Lidija M, Mihal D and Nikolaos K. 2011. The effect of colour shade nets on the greenhouse climate and pepper yield. Proceedings 46th Croatian and 6th International Symposium on Agriculture, Opatija, Croatia. Pp. 529532.

\section{How to cite this article:}

Naveena, N., S. P. Thamaraiselvi, K. R. Rajadurai and Sivakumar, R. 2020. Growth and Physiology of Boston Fern (Nephrolepis exaltata) as Influenced by Different Coloured Shade Nets. Int.J.Curr.Microbiol.App.Sci. 9(10): 111-116.

doi: https://doi.org/10.20546/ijcmas.2020.910.015 